\title{
COMPLEXES OF METALS WITH HYDRAZONE HYDRAZIDE SALICYLIC ACID
}

\author{
P.A. Fatullayeva \\ Acad. M. Naghiyev Institute of Catalysis and Inorganic Chemistry \\ of the National Academy of Sciences of Azerbaijan \\ AZ 1143 Baku, H. Javid ave.113, e-mail: pfatullayeva@mail.ru
}

Received 20.04.2021

Accepted 15.07.2021

\begin{abstract}
Complexes of $\mathrm{Cu}$ (II), Ni (II), and Co (II) with hydrazone derivatives of salicylic acid hydrazide and 3,5-di-tert-butyl salicylic aldehyde (LH) were synthesized and the structure of these compounds studied by means of elemental analysis methods, IR and electronic spectroscopy, magnetochemistry and thermal analysis. It revealed that the complexes are monomeric and have a composition [MLXSoI] where $M$ is a metal ion, $L$ is a ligand, $X$ is an inorganic anion, and Sol is a solvent molecule. LH- in the complexes behaves like a monoanionic tridentate ligand. It found that the resulting complexes exhibit noticeable inhibitory and urease activity.
\end{abstract}

Keywords: hydrazones, metal complexes, coordinated ligands

DOI: 10.32737/2221-8688-2021-2-79-83

\section{Introduction}

Derivatives of salicylic acid, belonging to the group of non-steroidal drugs, are classic anti-inflammatory drugs [I], and also have a pronounced antipyretic, analgesic and antioxidant effect [2].

The increased interest in complexes of this type is due, first of all, to intensive searches for new optical and magnetic materials (mainly molecular magnets), as well as effective adsorbents, chemical sensors, catalysts for technological and biochemical processes [3-7]. We have obtained and studied complexes of $\mathrm{Cu}$ (II), Ni (II) and Co (II) of hydrazone of salicylic acid hydrazide and 3,5-di-tert-butyl salicylic aldehyde.

\section{Experimental part}

IR spectra were recorded on a Specord-M40 infrared spectrophotometer (Carl Zeiss Jena) and Nicolet IS10 in the form of $\mathrm{KBr}$ tablets in the range of 4000-400 cm and vaseline oil.

Electronic spectra were recorded on an Evolution-60S spectrophotometer. Measurements of the magnetic susceptibility were carried out at room temperature on a Faraday-type apparatus using $\mathrm{Hg} / \mathrm{Co}(\mathrm{SCN}) 4]$ as a standard. In turn, thermogravimetric measurements were carried out on a NEIZSCHSTA 449F3 derivatograph and elemental analyzes performed in the analytical laboratory Tubitak, Ankara, on LECOCHNS 932 analyzer.
Synthesis of salicylic acid hydrazide.

Salicylic acid hydrazide was obtained through the use of [8] reaction of salicylic acid ethyl ester and $60 \%$ hydrazine solution.

Preparation of hydrazone from salicylic acid hydrazide and 3,5-di-tert-butyl salicylic aldehyde (LH).

To a weighed portion of $1.52 \mathrm{~g}(0.01 \mathrm{~mol})$ of salicylic acid hydrazide dissolved in $20 \mathrm{ml}$ of ethyl alcohol there was added $2.34 \mathrm{~g}(0.01 \mathrm{~mol})$ of 3,5-di-tert-butyl salicylic aldehyde in $25 \mathrm{ml}$ of ethanol. The reaction mixture was heated to reflux and left to crystallize. Yellow crystals precipitated, then separated and dried. TPL $=$ $235^{\circ} \mathrm{C}$. 
For: $\mathrm{C}_{22} \mathrm{H}_{28} \mathrm{~N}_{2} \mathrm{O}_{3}$

Calculated: C 71.74; H 7.61; N 7.61; O 13.04

Found: C71.60; H 7.48; N 7.54; O 13.12

Obtaining a Cu complex with a ligand (LH). To a weighed portion of $10^{-3} \mathrm{~mol}(0.369 \mathrm{~g})$ of Schiff's base dissolved in $30 \mathrm{ml}$ of ethanol there was added a solution of $10^{-3} \mathrm{~mol}(0.242 \mathrm{~g}) \mathrm{Cu}$ $\left(\mathrm{NO}_{3}\right)_{2} 3 \mathrm{H}_{2} \mathrm{O}$ in $10 \mathrm{ml}$ of methanol with stirring and heating at $50^{\circ} \mathrm{C}$. Then the resulting solution was filtered and left on cooling; green TPL crystals $>250^{\circ} \mathrm{C}$ precipitated from it.

For: $\mathrm{C}_{22} \mathrm{H}_{29} \mathrm{Cu} \mathrm{N} \mathrm{N}_{3} \mathrm{O}_{7}$.

Calculated: C 51.66; $\quad$ H 5.68; $\quad$ N 8.22 ;

$\begin{array}{lllll} & \text { O 21.92; } & \text { Cu 12.52. } & & \\ \text { Found: } \quad \text { C 51.50; } & \text { H 5.65; } & \text { N } & 8.26 \text {; }\end{array}$

$$
\text { O 21.80; } \quad \mathrm{Cu} 12.49 \text {. }
$$

Obtaining a Ni-complex with a ligand (LH) A mixture of $10^{-3} \mathrm{~mol}(0.369 \mathrm{~g})\left(\mathrm{H}_{4} \mathrm{sahz}\right)$ in 20 $\mathrm{ml}$ of ethanol and $10^{-3} \mathrm{~mol}(0.291 \mathrm{~g})$ of nickel nitrate $\mathrm{Ni}\left(\mathrm{NO}_{3}\right)_{2} \cdot 6 \mathrm{H}_{2} \mathrm{O}$ dissolved in $10 \mathrm{ml}$ of methanol was stirred on a magnetic stirrer at a temperature of $40-50{ }^{\circ} \mathrm{C}$ for $15-20$ minutes. After cooling the reaction mixture reached a room temperature, a fine crystalline light green powder precipitated. $\mathrm{T}_{\Pi л}:=240^{\circ} \mathrm{C}$.

For: $\mathrm{C}_{22} \mathrm{H}_{29} \mathrm{NiN}_{3} \mathrm{O}_{7}$

Calculated: C 52.20; H5.73; $\quad$ N 8.31; O 22.15; Ni 11.61 .

Found: C 52.10; H 5.68; N 8.22 ; O 22.17; Ni 11.63.

The Co (II) complex was obtained in a similar way. Dark red complex at $\mathrm{T}_{\Pi л}>250^{\circ} \mathrm{C}$.

For: $\mathrm{C}_{22} \mathrm{H}_{29} \mathrm{CoN}_{3} \mathrm{O}_{7}$

Calculated: C 52.20; $\quad$ H 5.73; $\quad \mathrm{N}$

$8.30 ; \quad$ O 22.14; Co 11.65.

Found: $\quad$ C 52.19; H5.63; N

8.22; O22.12; Co 11.71 .

\section{Results and discussion}

The IR spectrum of the Schiff base LH contains vibration bands of the $\mathrm{C}=\mathrm{N}$ and $\mathrm{C}=\mathrm{O}$ groups at $1612 \mathrm{~cm}^{-1}$ and $1634 \mathrm{~cm}^{-1}$, respectively. The $3196 \mathrm{~cm}^{-1}$ absorption bands can be attributed to the $\mathrm{N}-\mathrm{H}$ vibrations in the NHCO group. While the carbonyl band the CO group appears at $1639 \mathrm{~cm}^{-1}$. The absorption band of the band at $3079 \mathrm{~cm}^{-1}$ has a very low intensity and refers to the absorption of aromatic rings.

IR spectra of complexes of metals $\mathrm{Cu}(\mathrm{II}), \mathrm{Co}(\mathrm{II})$ and $\mathrm{Ni}(\mathrm{II})$ with hydrazone contain an absorption band of the azomethine group at $1612-1620 \mathrm{~cm}^{-1}$. Absorption band of amide carbonyl at $1640 \mathrm{~cm}^{-1}$. This confirms its participation in coordination with the metal ion. There is also an absorption peak at $3400 \mathrm{~cm}^{-1}$ related to coordinated water.

In the electronic absorption spectra of the Schiff base, absorption bands are observed at 210,265 , and $350 \mathrm{~nm}$. The first two bands can be attributed to $\Pi-\Pi^{*}$ transitions in benzene rings. The band at $350 \mathrm{~nm}$ refers to the $\mathrm{n}-\Pi^{*}$ transition in the $\mathrm{C}=\mathrm{N}$ group conjugated to the benzene ring.
On the thermogram of the $\mathrm{Cu}$ (II) complex in the temperature range of $50-102{ }^{\circ} \mathrm{C}$, a weight loss of $7.30 \%$ is observed accompanied by an endothermic effect and corresponding to the loss of hygroscopic water. In the range of $102-167^{\circ} \mathrm{C}$, a $5.43 \%$ mass loss is observed to comply with the loss of a coordinated water molecule. At temperatures above $240^{\circ} \mathrm{C}$, thermal oxidative destruction of the complex occurs, smoothly turning into the process of burning out the organic residue. The process is accompanied by an exothermic effect with a blurred maximum on the DTA curve in the region of $340^{\circ} \mathrm{C}$. The process of decomposition of the sample ends with a loss of $92.21 \%$ of its mass at $940{ }^{\circ} \mathrm{C}$. The remaining metal mass of $7.8 \%$ corresponds to a metal: ligand ratio in the complex equal to $1: 1$.

The obtained data of elemental analysis, PC and electron spectroscopy, as well as derivatography is in keeping with the preliminary obtained molecular structure of the $\mathrm{Cu}$ (II) complex (Fig. I) ${ }^{*}$.

*The data were obtained in the laboratory of Prof. V.N. Khrustalev. 


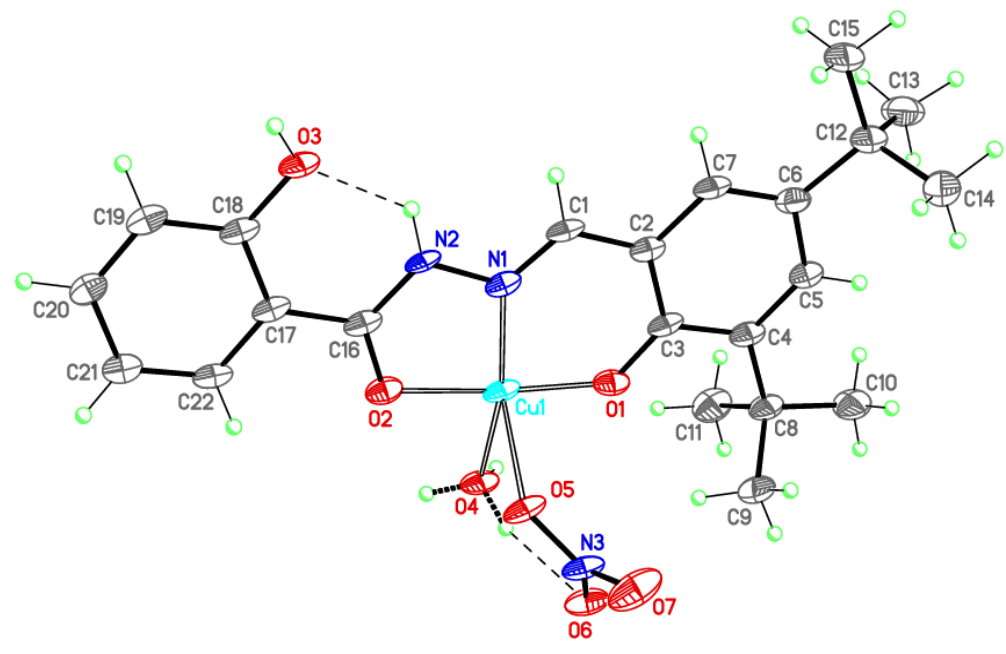

Fig. I. Molecular structure of the $\mathrm{CuL}\left(\mathrm{NO}_{3}\right)\left(\mathrm{H}_{2} \mathrm{O}\right)$ complex

The coordination environment of the $\mathrm{Cu}^{2+}$ ion in this complex has a distorted squarepyramidal structure with oxygen water molecule. The fourth position in the equatorial plane is occupied by the nitrogen atom of the hydrazine fragment. Completion to the pyramid is carried out by the oxygen of the nitro group.

In order to identify and evaluate the biological activity of the synthesized complex compounds, their antioxidant capacity and the ability to inhibit the enzyme urease were studied.

The analysis of inhibitory activity was performed by three methods: the FRAP method; DPPH and CUPRAC method and the urease activity to inhibit the breakdown of urea in the presence of the urease enzyme (table).

\section{FRAP analysis}

This was carried out by mixing solutions of the FRAP reagent (acetate buffer solution of tripyridyltriazine $\mathrm{FeCL}_{3}$ ) with a solution of the test substance; measuring the optical density at $593 \mathrm{~nm}$ and comparing the optical density values with those of the calibration table obtained by titration with a $\mathrm{FeSO}_{4} 7 \mathrm{H}_{2} \mathrm{O}$ solution. The FRAP value was expressed in $\mathrm{mM}$ $\mathrm{FeSO}_{4} / \mathrm{mg}$ test substance. The FRAP analysis was performed according to the method of Benzie and Strain [9].

\section{DPPH analysis}

DPPH analysis is based on radical scavenging with 1,1-diphenyl-2-picrylhydrazyl. The test substance and standard solutions to which DPPH solution was added, shaken for 1 minute and then kept in the dark at room conditions for 30 minutes. Optical density was measured relative to the reference at $517 \mathrm{~nm}$. The ability of the extracts to trap free radicals was determined according to the previously described method [10]. The data obtained from the study were presented as IC50 = mg $/ \mathrm{ml}$.

\section{Copper ion reductive / antioxidant analysis (CUPRAC)}

$60 \mathrm{mkl}$ of $\mathrm{Cu}$ (II) $\times 2 \mathrm{H}_{2} \mathrm{O}, 60 \mathrm{mkl}$ of neocuproin, and $60 \mathrm{mkl}$ of $\mathrm{NH}_{4} \mathrm{Ac}(1 \mathrm{M})$ were mixed. Then, $60 \mathrm{mkl}$ of the test substance and $10 \mathrm{mkl}$ of ethanol were added to the mixture. After 60 min, the absorbance of the mixture was measured spectrophotometrically at $450 \mathrm{~nm}$. The CUPRAC values of the studied substances are expressed in $\mathrm{mM}$ trolox / $\mathrm{mg}$ substance [11].

\section{Urease inhibition assay}

We used $100 \mathrm{mkl}$ of the working solution, added $500 \mathrm{mkl}$ of urease enzyme to it, and kept it in a temostat at $37^{\circ} \mathrm{C}$ for 30 minutes. Later, $1100 \mathrm{mkl}$ of urea was added to this mixture and kept in a thermostat at $37^{\circ} \mathrm{C}$ for 30 minutes. Reagents Rl ( $1 \%$ phenol, $0.005 \%$ sodium nitroprusside) and R2 $(0.5 \% \quad \mathrm{NaOH}, 0.1 \%$ sodium hypochlorite) were added to the mixture taken out of the thermostat, and the mixture was kept at $37^{\circ} \mathrm{C}$ in a thermostat for 2 hours. The absorbance of the mixture was regarded relative to the reference at $635 \mathrm{~nm}$. The anti-urease activity of the extracts was assessed by the indophenol method [12]. The results of this 
study are expressed as percent inhibition of the urease enzyme.

Table. Analysis of the inhibitory activity of the synthesized complex compounds

\begin{tabular}{|l|c|c|c|c|}
\hline Combinations & $\begin{array}{l}\text { DPPH } \\
\left(\mathrm{IC} C_{50} \mathrm{mg} / \mathrm{ml}\right.\end{array}$ & $\begin{array}{l}\text { FRAP } \\
\mathrm{mMFeS} 0_{4} / \mathrm{mg}\end{array}$ & $\begin{array}{l}\text { CUPPAK } \\
\mathrm{mMTE} / \mathrm{mg}\end{array}$ & $\begin{array}{l}\text { Inhibiting of urease } \\
(\%) 6.25 \mathrm{mg} / \mathrm{ml}\end{array}$ \\
\hline $\mathrm{Cu}(\mathrm{LH})\left(\mathrm{NO}_{3}\right)\left(\mathrm{H}_{2} \mathrm{O}\right)$ & 0.063 & 59.4 & 0.834 & 9.578 \\
\hline $\mathrm{Co}(\mathrm{LH})\left(\mathrm{NO}_{3}\right)\left(\mathrm{H}_{2} \mathrm{O}\right)$ & 0.059 & 58.00 & 0.823 & 9.356 \\
\hline $\mathrm{Ni}(\mathrm{LH})\left(\mathrm{NO}_{3}\right)\left(\mathrm{H}_{2} \mathrm{O}\right)$ & 0.061 & 56.78 & 0.830 & 9.320 \\
\hline Ascorbic acid & 0.0028 & & 1.83 & \\
\hline BHA & & 86.00 & & 42.12 \\
\hline Thiourea & & & & \\
\hline BHT & & & & \\
\hline
\end{tabular}

Thus, as is seen from table, the obtained ureasis effect. compounds have a noticeable inhibiting and

\section{References}

1. Nasonov E.L., Labeznik L.B., Mareev V.Yu. et al. The use of non-steroidal antiinflammatory drugs. Clinical guidelines. Moscow: 2006.

2. Randjelovic P., Veljkovic S., Stojiljkovic N., Sokolovic D., Ilic I., Laketic D., Randjelovic D., Randjelovic N. The Beneficial Biological Properties of Salicylic Acid. Actafacultat is medicae Naissensis. 2015, vol. 32(4), pp. 259-265.

3. Shen Lin, Shi-Xiong Liu, Jian-Quan Huang and Chi-Chang Lin. Four novel nanometer-sized cobalt azametallacrown complexes. J.Chem.Soc., Dalton Trans. 2002, issue 8, pp. 1595-1601.

4. Xinwen Zhang, Lamei Wu, Jian Zhang and Longfei Jin. Synthesis, Crystal Structure, and Bioactivity of a Novel Iron(III) 18Metallacrown-6 Complex. Synthesis and Reactivity in Inorganic, Metal-Organic, and Nano-Metal Chemistry. 2012, vol. 42, pp. 171-177.

5. Arpi Majumder, Sanchita Goswami, Stuart R. Batten et al. Catalytic oxidation of 3,5-ditert-butylcatechol by a manganese(III) 18azametallacrown-6 compound: Synthesis, crystalstructure, fluorescence, magnetic and kinetic investigation. Inorganica Chimica
Acta. 2006, vol. 359, pp.2375-2382.

6. Gustavo Duarte de Souza, Monika Aparecida Rodrigues, Priscila Pereira Silva [et al.]. A New complex of Palladium(II) With 2-Furoic Hydrazide: Synthesis, Characterization, Theoretical Calculations and Biological Studies. Croat.Chem.Acta. 2013, vol. 86, no. 2, pp. 201-206.

7. Terzioglu N., Gürsoy A. Synthesis and anticancer evaluation of some new hydrazone derivatives of 2,6-dimethylimidazo[2,1-b]$[1,3,4]$ thiadiazole-5-carbohydrazide. Eur. $J$. Med. Chem. 2003, vol. 38, p. 781.

8. Furniss B.S. Vogel's: Textbook of practical Organic Chemistry. / B.S.Furniss, A.J.Hannaford, P.W.G.Smith, A.R.Tatchell. Longman Group UK Limited, 1989, 1269 p.

9. Benzie I.F, Strain J.J. The Ferric Reducing Ability of Plasma (FRAP) as a Measure of "Antioxidant Power": The FRAP Assay. Analytical Biochemistry. 1996, vol. 239, pp. 70-76.

10. Taşkın T., Taşkın D., Cam M-E, Bulut G. Phenolic compounds, biological activities and trace elements of Capparis ovata var. canescens. Revista de Biología Tropical. 2020, vol. 68, no. 2, pp. 590-600. 
11. Taşkın D., Dilek B. A, Dölen E. Evaluation of Antioxidant Capacity and Analysis of Major Phenolic Compounds in Achillea grandifolia by HPLC-DAD with Q-TOF LC/MS Confirmation. Chiang Mai J. Sci. 2018, vol. 45 , no. 1 , pp. 287-298.
12. Taskin T., Balkan I.E., Tankin D. and Dogan A. Characterization of Phenolic Constituents and Pharmacological Activity of Achillea vermicularis. J Pharm Sci., 2019, vol. 81, no. 2, pp. 293-301.

\section{SALISIL TURŞUSU HIDRAZIDININ HIDRAZONU ILO METAL KOMPLEKSLORI}

\section{P.Ө. Fotullayeva}

AMEA akademik M.Nă̆ıyev adına Kataliz vo Qeyri-üzvi Kimya İnstitutu AZ 1143 Bakl, H. Cavid prospekti 113, e-mail: pfatullayeva@mail.ru

Salisil turşusu hidrazidinin hidrazonu va 3,5-di-tret-butil salisil aldehidi (LH) töramalari ilo $\mathrm{Cu}(I I), \mathrm{Ni}$ (II) va Co(II) komplekslari sintez edilmişdir. Bu birlaşmalarin quruluşu elementar analiz, $\dot{I Q}$ va elektron spektroskopiya, maqnit kimyası vo termiki analiz üsulları ilo öyrənilmişdir. Komplekslarin monomer olduğu va [MLXSol] tarkibina malik olduğu göstərilmişdir. Burada M metal ionu, L - ligand, X - qeyri-üzvi anion, Sol isa halledici molekuludur. Komplekslarda LH liqandı özunu monoanion tridentat ligand kimi aparır va alınan komplekslar nəzərə çarpan ingibitor vo ureaz aktivliyi nümayiş etdirir.

Açar sözlor: hidrazonlar, metal komplekslari, koordinasiya olunmuş ligandlar

\section{КОМПЛЕКСЫ МЕТАЛЛОВ С ГИДРАЗОНОМ ГИДРАЗИДА САЛИЦИЛОВОЙ КИСЛОТЫ}

\section{П.А. Фатуллаева}

Институт Катализа и Неорганической Химии им. акад. М. Нагиева Начиональной АН Азербайджана AZ 1143 Баку, пр. Г. Джавида 113, e-mail: pfatullayeva@mail.ru

Синтезированы комплексы Cu(II), Ni(II) и Co(II) с производными гидразона гидразида салициловой кислоть и 3,5-дитретбутилсалицилового альдегида(LH). Методами элементного анализа, ИК и электронной спектроскопии, магнетохимии и термическим анализом изучено строение этих соединений. Показано, что комплексы являются мономерныли и имеют состав [MLXSol], где $M$ - ион металла, L - лиганд, X- неорганический анион, Sol - молекула растворителя. LH в комплексах ведет себя как моноанионный тридентатный лиганд. Найдено, что полученные комплексы обладают заметной ингибирующей и уреазной активностью

Ключевые слова: гидразоны, комплексы металлов, координированные лиганды 